Hargitai, Peter. "Kányádi, Sándor. 2013. In Contemporary Tense (trans. Paul Sohar). Arad, Romania: Irodalmi Jelen Könyvek. Published in the United States by Iniquity Press. 342 pages." Hungarian Cultural Studies. e-Journal of the American Hungarian Educators Association, Volume 9 (2016): http://ahea.pitt.edu DOI: 10.5195/ahea.2016.264

\title{
Kányádi, Sándor. 2013. In Contemporary Tense (trans. Paul Sohar). Arad, Romania: Irodalmi Jelen Könyvek. Published in the United States by Iniquity Press. 342 pages.
}

\section{Reviewed by Peter Hargitai, Poet Laureate, Gulfport, Florida}

The noted English poet and critic George Szirtes and I agree that, in the main, it is the musicality of Sándor Kányádi's verse that accounts for his popularity as the most beloved living Hungarian poet. I would venture to add that his stature as a national poet is further enshrined since he is a true blue Székely from Transylvania, a region revered by Hungarians as something akin to sacred land. Over the centuries the Székelys have considered themselves the proud descendents of Attila the Hun, with a vanguard role in defending, shaping and preserving what is quintessentially Hungarian. It is this geographical outpost in the Carpathians that Hungary lost to Romania after the Trianon Treaty of 1920 that stripped Hungary of three quarters of its territory and left 1,600,000 fiercely independent Székely inhabitants torn from their mother country. A once-proud people now became an oppressed minority in Romania, their human rights violated, their churches, language and culture under constant attack, severe enough to spark a revolt during the brutal regime of Nicolae Ceauşescu.

Sándor Kányádi the poet (b. 1929) not only survived, but his language soared, and his single-handed revival of lyric poetry in both Hungarian and Romanian would eventually lead the official Romanian Writers Union to award him their highest prize, to be followed by one prestigious literary award after another, including the Kossuth Prize from Hungary, the German Herder Prize, and the Central European Time Millennium Prize. The sound effects invested in Kányádi's verse are never artificial but seem to evolve organically and effortlessly in an ingenuous chorus of traditional end-rhymes, internal rhymes, delayed rhymes, approximate rhymes, subtle assonances and sibilants that together create richly nuanced embroideries of harmony, neither sentimental nor anachronistic, but simply melodic. In short, Kányádi is a born poet, a wunderkind, in the same vein as were Edgar Allan Poe (1809-1849) and Percy Bysshe Shelley (1792-1822). He could have easily penned lines like, "Ah distinctly I remember, it was in the bleak December; / And each separate dying ember ..." from Poe's "The Raven" or a verse from Shelley's "The Cloud": "I am the daughter of Earth and Water, / And the nursling of the Sky; / I pass through the pores of the ocean and shores; / I change, but I cannot die."

There is no poet known to the English speaking world that is as admired in his own country as Sándor Kányádi. His poems have been delighting generations of Hungarian readers of all ages and he is especially popular with children. But he is not for everybody, certainly not for elitists, those two percents of the population, usually scholar-poets with their tortured cerebral puzzles, or for minimalists, insufferable oblique imagists, or for prose-poets with their longsuffering strings of words presented in numbered chapbooks. The problem with Aristo art is that sooner or later the public becomes savagely bored with it because they want to break out into

$(\mathrm{cc}) \mathrm{BY}$

ULLS D-Serle 
Hargitai, Peter. “Kányádi, Sándor. 2013. In Contemporary Tense (trans. Paul Sohar). Arad, Romania: Irodalmi Jelen Könyvek. Published in the United States by Iniquity Press. 342 pages." Hungarian Cultural Studies. e-Journal of the American Hungarian Educators Association, Volume 9 (2016): http://ahea.pitt.edu DOI: 10.5195/ahea.2016.264

song, they want to dance, and this is not at all about the urban-versus-folk literature debate or about ideology or any nationalistic agenda.

To select and translate poems from Kányádi's vast oeuvre in a hefty volume of 342 pages which contain 339 poems, and to do so in a way that they resonate with the same startling lyrical immediacy as in their original Hungarian is well nigh impossible. The task is monumental and the process all the more arduous due, in large measure, to the nature of the Hungarian language. Linguists would agree that because of its agglutinative syntax, rhyming comes easier in Hungarian than in English, and that Hungarian naturally lends itself to intense musicality partly because its suffixes create natural assonances and thus make sounds come to life as if by magic. If anyone can come up to try the impossible and save what is usually lost in translation, it is Paul Sohar, an American poet who writes in both English and Hungarian with convincing power and who recently won the Árpád Tóth Translation Award in Budapest. Sohar is not only perfectly bilingual but also an award-wing translator with an eminent publishing history in a poetic terrain that is uniquely Székely. His task in preparing this recent volume was to convey the unique harmonies of the original poems and at the same time make them sound contemporary, even if the Romantic lyricism of Kányádi's poems is anything but that. Therefore, the very title, In Contemporary Tense, may strike us as a sleight of hand, but on further review it is not, and least of all in the sense of contemporary populist poetry.

In Contemporary Tense presents its 339 poems chronologically and in sections corresponding to Kányádi's published volumes. Among its nineteen sections, the most popular ones are "Black and Red Verses," "All Souls Day in Vienna," "Mane and Skull" and "The Curious Moon" (for children); but "There Are Regions" must be a particular favorite as it has so far been translated into Romanian, Finish, Swedish, Estonian, German, French, and Portuguese. The "Prologue" from "There Are Regions" (1982) is a good place to begin a comparative look at the original and its English translation by Sohar: 
Hargitai, Peter. "Kányádi, Sándor. 2013. In Contemporary Tense (trans. Paul Sohar). Arad, Romania: Irodalmi Jelen Könyvek. Published in the United States by Iniquity Press. 342 pages." Hungarian Cultural Studies. e-Journal of the American Hungarian Educators Association, Volume 9 (2016): http://ahea.pitt.edu DOI: 10.5195/ahea.2016.264

\author{
ELÖHANG \\ vannak vidékek gyönyörü \\ tájak ahol a keserü \\ számban édessé izesül \\ vannak vidékek legbelül \\ szavak sarjadnak rétjein \\ gyopárként sziklás bércein \\ szavak kapaszkodnak szavak \\ véremmel rokon a patak \\ szívemmel rokon a patak \\ szívemben csörgedez csobog \\ télen hogy védjem befagyok \\ páncélom alatt cincogat \\ jeget-pengetö hangokat \\ tavaszok nyarak öszeim \\ maradékaim s öseim \\ vannak vidékek viselem \\ akár a bört a testemen \\ meggyötörten is gyönyörü \\ tájak ahol a keserü \\ számban édessé izesül \\ vannak vidékek legbelül
}

\section{PROLOGUE}

there are regions beauty-laced

landscapes where the bitter taste

and sweetness on my tongue collide

there are regions deep inside

on their meadows phrases sprout

flower words gush blooming out

words hang on to words on peaks

my blood is cousin to all creaks

in my heart it comes and flees

to save it in winter I have to freeze

under ice armor it squeaks and sings

plucking crystal melody flings

my springs and summers turn to fall

my heirs and forebears are they all

there are regions that I live in

wearing them just like my skin

tortured through they're beauty-laced

landscapes where the bitter taste

and sweetness on my tongue collide

there are regions deep inside (222-223)

Sohar's English version comes very close to conveying the symbiosis of sound and sense in this bitter-sweet stanza. A less successful English translation of the same poem by the late Peter Zollmann, entitled "There is a Land," strays wide of the mark with Zollmann's offering of the collective noun "land" for 'vidékek.' Zollmann's wording comes close to a mistranslation as the two terms are neither syntactically nor semantically equivalent, because "land" means a country and not part of a country as the poet intended; moreover, Sohar's "regions," unlike Zollmann's "land," is plural like Kányádi's original 'vidékek.' It may be useful to look further at Zollmann's translation to demonstrate the great pains Sohar has taken to preserve the poet's trademark musicality. The Zollmann version of the first three lines sounds almost prosaic: "there is a land with beauty graced / landscapes where the bitter taste / that fouls my mouth is purified." Save for some approximate assonance between "landscapes" and "taste" and the rather clumsy "foul" and "mouth," the quintessential Kányádi verse is lost in this translation.

(http://www.leafepress.com/litter1/noon02.html)

In the first four lines of ELÖHANG the original Hungarian has true three-syllabic endrhymes (AABB), coupling 'gyönyörü' with 'keserü' and 'izesül' with 'legbelül.' Moreover, there are delightful plays of assonance as one vowel-sound after another is repeated and echoed in the end-rhymes themselves. The 'é' phoneme in 'vidékek' is assonant in the first and last letters in 'édessée' and the coupling end-rhymes are also assonant with each other in the stressed and

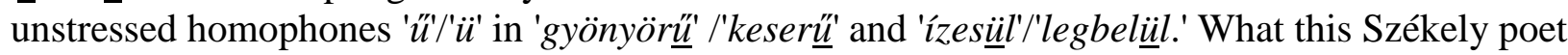
is trying to say in these lines is that discovering, generating and regenerating a language with such a musical range make the "bitter taste" of loss taste sweet in his mouth, and in this way 
Hargitai, Peter. “Kányádi, Sándor. 2013. In Contemporary Tense (trans. Paul Sohar). Arad, Romania: Irodalmi Jelen Könyvek. Published in the United States by Iniquity Press. 342 pages." Hungarian Cultural Studies. e-Journal of the American Hungarian Educators Association, Volume 9 (2016): http://ahea.pitt.edu DOI: 10.5195/ahea.2016.264

language itself becomes life and identity affirming. As the lines that emerge transform his pain, the poet hangs on to every word as if he were hanging on for his life on some treacherous mountain crag, just as his people tried to hang on to their regional identity and culture. When the Székelys were listening to the poet reading this poem and others like it on old 1980s cassettes, they must have felt a resurgence of their old grandeur as the magical language they had thought was lost was not only found but displayed for them in bewitching chords.

Sándor Kányádi, the poet of the people or something as close as can be to a national poet, was born in an obscure little Transylvanian village and he often reminisces about swineherds, geese and goats, oxen, foals and the joys of the harvest. The revered New England poet Robert Frost (1874-1963), perhaps the best-known of America's regional poets, also wrote about foals and mending fences, and did so in traditional rhyme; at the same time, his verses are, more often than not, profound meditations on existence. Kányádi, too, wrote poems that demand rigorous intellectual engagement. His iconic “All Souls Day in Vienna” (1976) has been compared to T.S. Eliot's "The Wasteland" and not frivolously so as its kindred tone is unmistakably Eliotesque. Since, as poet and translator Paul Sohar reminds us in his review of several Radnóti translations in this very volume, poetry translation is all -- or much -- about the translation, I will henceforth present parts of his translations of Kányádi's poetry rather than the Hungarian original:

It is said and even recorded in the histoire de la musique encyclopédie de la pléiade but also in kolozsvár at number ten vasile alecsandri street my friend dr rudi schuller will happily translate into hungarian german or romanian for those who don't speak french the part about the grand travelers les grands voyageurs who claimed that the inhabitants of the most godforsaken les plus lointaines civilizations who were totally indifferent to the tom-toms of neighboring tribes would perk up their ears only on hearing mozart's music (151)

To those pundit critics who dismiss Kányádi as a lightweight who lacks suggestion and irony, I offer his poem "Knives" (1968), which is short enough to quote here in its entirety:

Knives' gleam flickers in me,

I've an urge to grab them, throw them, stab them all and all at once.

Carefully I pick one out, the sharpest, and guided by tenderness I slice off a piece of bread for my son (74). 
Hargitai, Peter. "Kányádi, Sándor. 2013. In Contemporary Tense (trans. Paul Sohar). Arad, Romania: Irodalmi Jelen Könyvek. Published in the United States by Iniquity Press. 342 pages." Hungarian Cultural Studies. e-Journal of the American Hungarian Educators Association, Volume 9 (2016): http://ahea.pitt.edu DOI: 10.5195/ahea.2016.264

To those who criticize the poet for saying more about Armenian woodcarving than Transylvanian gates, I say he is cosmopolitan, and that they should read his "Brief Encounter With Cartagena" (1985, p. 176). To those who criticize him for being too cosmopolitan, I say, read about his childhood's "smoke-smelling / covered wagon" in "The Gypsy Caravan" (1976, p. 125). To those who say he is an anti-Semite because he doesn't like big cities or abstract art, I say, read "Unexpected Yellow" (1993):

\section{A note to go under a painting entitled Unerwartetes Gelb by András Markos}

the unexpected yellow

showed up unexpectedly

and yellowed into the mint-

mellow and curdled blood

of unexpectedness

all black lines wiggled into

worms and then a mess of cocoons

a capital $\mathrm{T}$ fell flat on its back

turning blacker than black when

someone called me a dirty jew

and if I'd walked bent under the weight

of just one millennium before then

unexpectedly I aged by

four thousand years more (234)

This poem is provocative on several levels, including the personal. The subject is a nonrepresentational painting by Transylvanian sociologist and archivist András Markos (19201974). As bizarre as it may seem, one's views on non-representational art is still used by some misguided academics as a sort of litmus-test for anti-Semitism. When as a first-year lecturer at the University of Miami I was "interrogated" by a colleague about my views on nonrepresentational art, I told him that I preferred Tivadar Csontváry over Jackson Pollock. I was immediately labeled a Fascist, until a personal letter from the renowned Israeli poet Yehuda Amichai (1924-2000) came to my rescue. Sadly, I have lost touch with Amichai over the years, but Sándor Kányádi has not and he pays moving tribute to the memory of the celebrated Jerusalemite poet in his poem "The City." 
Hargitai, Peter. "Kányádi, Sándor. 2013. In Contemporary Tense (trans. Paul Sohar). Arad, Romania: Irodalmi Jelen Könyvek. Published in the United States by Iniquity Press. 342 pages." Hungarian Cultural Studies. e-Journal of the American Hungarian Educators Association, Volume 9 (2016): http://ahea.pitt.edu DOI: 10.5195/ahea.2016.264

To those who say that Kányádi's work is all about show and has no substance, I say, read "From the Diary of a Pilgrim" (1978) for its elegant simplicity and surprising irony:

I've been stunned by the truly stunning beauty of the great cathedrals abroad but to pray I could be moved only in my childhood's old village church if so I could be moved (145)

To those who say that he is out of touch with the human condition, I say, read "Evening Scene" (1965):

The boy tears out of the house, inside it's dad smacking mom around.

The kid puts his hand on his ears against the horror.

He'd like to run out of the world, but the darkness sends him back sobbing under the meager light of a window where the sight of a moth bumping against the pane slowly smother his sobs (55).

And to all those who dismiss poet Sándor Kányádi for not being contemporary enough, I say: read In Contemporary Tense. 